\title{
QUALITY ASSESSMENT OF GROUNDWATER OF ALMADINAH ALMUNAWARAH CITY
}

\author{
SHRAIM A.M. ${ }^{1,2, *}$ \\ ALSUHAIMI A.O. ${ }^{1}$ \\ AL-MUZAINI K.0. ${ }^{1}$ \\ KURDI K. ${ }^{3}$ \\ AL-AMEEN H. ${ }^{3}$
}

\author{
${ }^{1}$ Chemistry Department, Faculty of Science and \\ Toxicological Research and Studies Centre, \\ Taibah University, Saudi Arabia \\ 2 The University of Queensland, National Research Centre \\ for Environmental Toxicology (Entox), Queensland, Australia \\ ${ }^{3}$ Almadinah Almunawarah Municipality Lab for Food \\ Analysis and Environmental Research, Saudi Arabia
}

Received: $29 / 08 / 12$

Accepted: $15 / 04 / 13$ *to whom all correspondence should be addressed: e-mail: ashraim@taibahu.edu.sa; a.shraim@uq.edu.au

\begin{abstract}
Renewable water resources in Saudi Arabia are limited with groundwater as the major source for water supply. This study was conducted to assess the quality of groundwater in Almadinah Almunawarah, Saudi Arabia. Water samples were collected from 60 wells in 2010. Physical and chemical parameters were examined. The results of colour, turbidity, odour, $\mathrm{pH}$, and nitrite in all samples were below the local drinking water guideline values. The fluoride concentrations in $8 \%$ of the samples were higher than the guideline value. The taste in $87 \%$ of the samples was unacceptable. Intolerable levels of both total hardness and TDS were found in most of the samples $(\sim 83 \%)$. Nitrate levels were above the guideline value in $65 \%$ of sample. Most of the samples $(80-$ $87 \%$ ) have failed the guidelines for sodium, chloride, and sulfate. On the other hand, none of the samples was found to contain $\mathrm{Cr}, \mathrm{Ni}, \mathrm{Cu}, \mathrm{Zn}, \mathrm{Cd}, \mathrm{Ba}$, and $\mathrm{Pb}$ exceeding the guideline values. However, $5 \%$ of the samples have As concentrations over the limit (results 12.0-29.0 $\mathrm{mg} \mathrm{L}^{-1}$ ). Similarly, $5 \%$ of the samples have Fe concentrations (320-589 $\left.\mathrm{\mu g} \mathrm{L}^{-1}\right)$ in excess of the guideline value. The level of $\mathrm{Mn}$ in only one sample $\left(183 \mu \mathrm{g} \mathrm{L}^{-1}\right)$ was greater than the guideline value and $10 \%$ of the samples have $\mathrm{Mg}$ (range 159000-210000 $\mathrm{gg} \mathrm{L}^{-1}$ ) above the limit. Although the water of the investigated wells does not satisfy many of the general drinking water guidelines due to the local environment and climate, most of the samples are in compliance with the guideline values for metals in drinking and irrigation water.
\end{abstract}

KEYWORDS: metals; water quality parameters; arid environment; Saudi Arabia.

\section{INTRODUCTION}

The aim of this work is to assess the chemical and physical quality of the groundwater in the city of Almadinah Almunawarah in Saudi Arabia.

The Arabian Peninsula is located in southwest Asia; a region that is distinguished by its aridity and dry environment along with very limited natural fresh water resources (Alhumoud et al., 2010; Alsharhan et al., 2001; Assubaie, 2011 in press; Haddadin, 2002). However, the region is rich in petroleum and mineral resources and has therefore hosted massive related industries which have a great potential to impact the quality of natural water resources (Sadiq and Alam, 1997; Sharma and Al-Busaidi, 2001). During the last fifty years, the region has experienced rapid industrial and economic developments accompanied by a large increase in the number of population which resulted in a higher demand on freshwater, mainly for human consumption and agricultural activities (Al-Senafy and Abraham, 2004; Husain et al., 1991; Murad and Krishnamurthy, 2004). As a consequence, the assessment of the quality and quantity of such limited water resources becomes an imperative tool to manage these resources in the best possible manner for any future sustainable development. 


\section{MATERIALS AND METHODS \\ Study area}

Almadinah Almunawarah (elevation 600-630 m, latitude: 24 28N, longitude: $3936 \mathrm{E}$ ) is a historical city located in Hejaz region in the north-western part of the Kingdom of Saudi Arabia (KSA) and it is located $190 \mathrm{~km}$ away from the Red Sea. The area of the City is about $600 \mathrm{~km}^{2}$ and its population according to the 2010 census is more than 1.1 million. Due to its religious significance, the City is distinguished by receiving a huge number of pilgrimages and visitors every year. In 2011 for instance, the number of visitors has exceeded 8 million from all parts of the world and this number is expected to double in the coming years. The average annual low and high temperatures for 2011were 12-29 and $22-41^{\circ} \mathrm{C}$, respectively. The highest recorded temperature in the same year was $47^{\circ} \mathrm{C}$ (June - August) and the lowest was $1{ }^{\circ} \mathrm{C}$ (December - March ). The City experiences irregular rainfalls, mainly in Winter and early Spring with an average rainfall of about $50 \mathrm{~mm}$. However, the neighbouring areas receive more frequent and heavier rainfalls (up to $200 \mathrm{~mm}$ ) (Weatherbase).

The City is located on a flat mountainous plateau and surrounded by a number of volcanic mountains from the north and southwest sides and the soil surrounding it is mostly basalt. It has several dry springs and valleys, which used to be rivers during the rainy ages. Among these important valleys (wadis) are Wadi Al-'Aqeeq, Wadi But'haan, Wadi Mahzoor, Wadi Mudthaineeb, Wadi Qunaah, and Wadi Raanoonaa (Almadinah Almunawarah Encyclopedia).

Due to its location in arid environment, its natural geography, and scarcity of rainfall especially in later decades, the area currently lacks major water bearing aquifers (Al-Harbi et al., 2006). The groundwater in the city (depth $15-200 \mathrm{~m}$ ) is mainly charged by local damps, mostly after rainy seasons (Saudi Arabia Ministry of Economy and Planning, 2004). Therefore the groundwater is almost the single source for irrigation in the area. Irrigation water is obtained through dug wells in farms. The number of water wells in the study area (inside the $3^{\text {rd }}$ Ring Road) is about 800 wells. However, treated domestic wastewater is also used for irrigation in Al-Khlail wadi at the northern part of the city (Shraim et al., 2011). During the last 20 years, the city starts to rely on seawater desalinations to face the increased demand on fresh water. Nowadays, the major source of domestic water for the city is desalinated water that is pumped from Yanbu Power and Desalination plant at the Red Sea. However, this water is sometimes partially mixed with local groundwater inside the city. Although the desalinated water is the main source of domestic supply, bottled water produced by private treatment factories from local groundwater wells is largely consumed by the residents and visitors of the city. Additionally, groundwater is sometimes used by farmers and residents of many villages for drinking and cooking, often, without any pretreatment. These reasons necessitate regular assessment and monitoring studies for the groundwater so as to provide accurate data about this valuable water resource.

The locations of investigated groundwater wells are shown in Figure 1.

\section{Chemicals and solutions}

All reagents and standards were prepared in ultra-pure water $(18.2 \mathrm{M} \Omega \mathrm{cm}$, Milli-Q Gradient from Millipore, USA). Nitric acid (90\% fuming) was obtained from Fisher Scientific (New Jersey, USA), ICP-MS multi-element calibration standards from Agilent $\left(10 \mu \mathrm{g} \mathrm{mL} \mathrm{m}^{-1}\right.$ each (USA), analytical reference material (TM-26.3) from Environment Canada, and certified wastewater from High-Purity Standard (CWW-TM-D, $20 \mu \mathrm{g} \mathrm{Hg} \mathrm{L}^{-1}$, Charleston, USA).

\section{Equipment}

An Inductively Coupled Plasma Mass Spectrometer (ICP-MS, 7500cx, Aglinet Technologies, Japan) was used for metals analysis. The operational parameters applied were listed elsewhere (Shraim et al., 2011). A Flame Photometer (PFP7, Jenway LTD, Felsted, England) was employed for sodium measurements. Residual chlorine, fluoride, nitrate, nitrite, phosphate, and sulfate were analysed using a DR2000 spectrophotometer (Hach Company, Loveland Colo USA). Hardness and chloride measurements were carried out using a digital titrator (Hach Company). Total dissolved solids (TDS) were measured using a conductivity meter (CO150, Hach Company, Loveland Colo, USA) and finally, $\mathrm{pH}$ measurements were performed using a pH meter (HANNA 211, Mauritius, Portugal). 


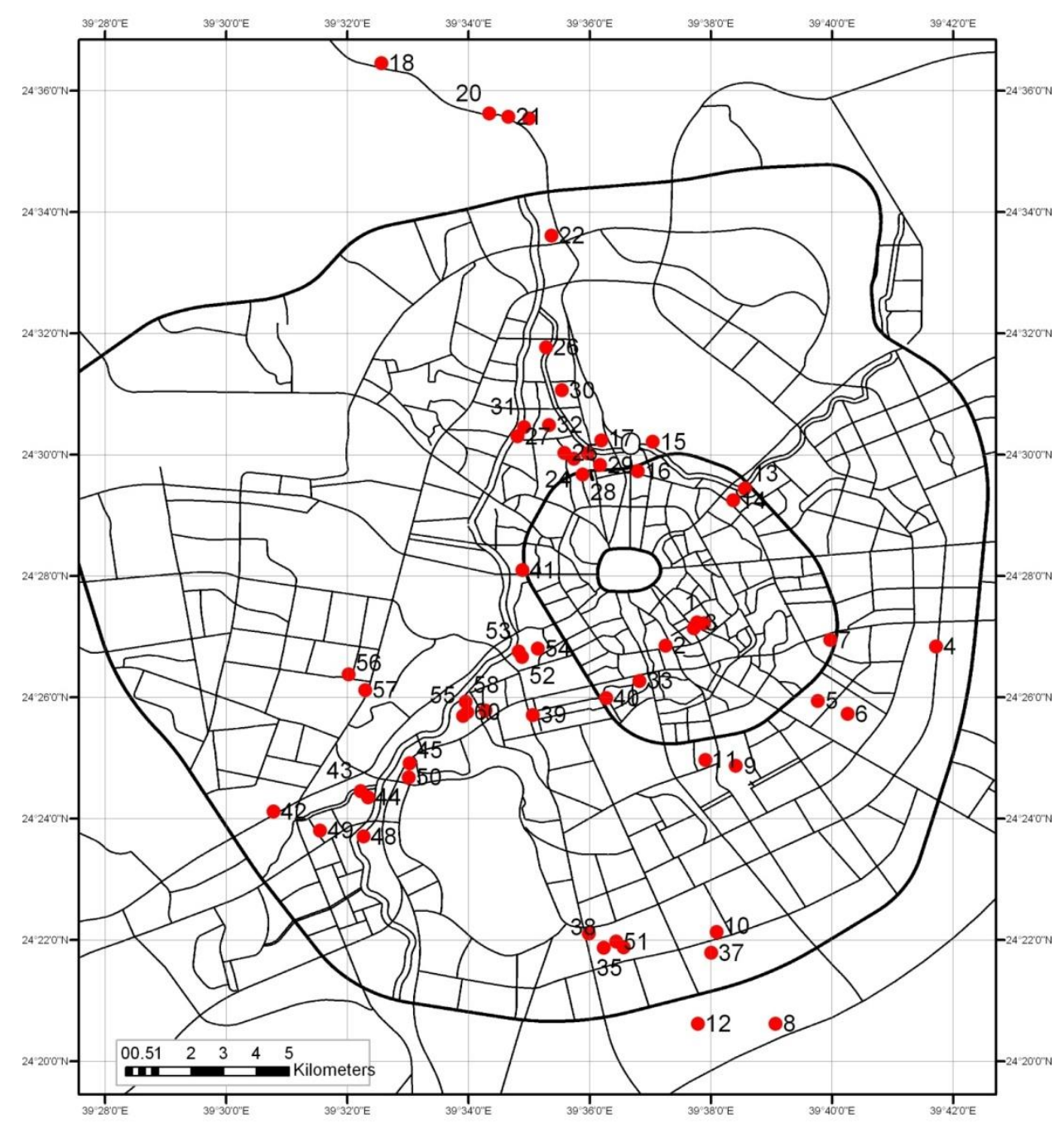

Figure 1. Locations and numbers of sampled water wells in Almadinah Almunawarah city

\section{Samples collection and analysis}

Sixty groundwater samples were collected from wells inside the city in June and July, 2010 (see Figure 1). Samples were collected directly from the wells in $10 \mathrm{~L}$ clean polyethylene bottles after about 10 min of initial pumping. Collected samples were transported to the laboratory within 2-3 hours after collection without any onsite pre-treatment. Upon arrival to the laboratory, each sample was split into 3 parts: the first one was used for metals and total hardness analyses; the second one was used for phosphate and the sum of nitrate and nitrite analyses; whereas the last part was used for TDS, nitrite, chloride, fluoride, and sulfate analyses. Physical parameters (i.e. temperature, $\mathrm{pH}$, turbidity and TDS) were measured immediately after arrival to the laboratory using portions from the third part before refrigeration. The first part was acidified with nitric acid $(1+1)$ to a $\mathrm{pH}$ of 2 or less immediately after arrival to the laboratory and stored inside a refrigerator at $4^{\circ} \mathrm{C}$ until analysed. Metals analysis was carried out within 2 weeks after collection using $0.22 \mu \mathrm{m}$ filtered undiluted samples. Subsamples of the second part were treated in the same way as the first one, but sulphuric acid $(1+1)$ was used instead of nitric acid. No treatment was done for the samples in the third part other than storing in a refrigerator at dark for 24 hours before analysis. 


\section{RESULTS AND DISCUSSION \\ General quality parameters}

The depth of water in the investigated groundwater wells, ranged from 35-160 m (average 89 $\pm 34 \mathrm{~m}$, median $90 \mathrm{~m}$ ). Table 1 lists the general quality parameters of the groundwater samples.

The obtained results of colour, turbidity, odour, $\mathrm{pH}$, and nitrite in all samples were below the Saudi Arabian Standards Organisation (SASO) drinking water guideline values. The fluoride concentrations in 5 samples (8\%) were above the guideline value (the max detected value was $2.2 \mathrm{mg} \mathrm{L}^{-1}$ ). The taste in $87 \%$ of the samples $(n=52)$ was not acceptable. High levels of both total hardness and TDS were found in most of the samples (about $83 \%$ of the samples failed the guideline values). The measured amounts of nitrate were relatively high with $65 \%(n=39)$ of the sample over the guideline value. Most of the samples (80-87\%) have also failed the guidelines for sodium, chloride, and sulfate contents. According to the Water Quality Association, which classifies water based on TDS levels, only $17 \%$ of the groundwater samples can be classified as fresh $\left(<1000 \mathrm{mg} \mathrm{L}^{-1}\right), 78 \%$ as brackish (1000-5000 $\mathrm{mg} \mathrm{L}^{-1}$ ) and only $5 \%$ as highly brackish (>5000-15000 $\mathrm{mg} \mathrm{L}^{-1}$ ) (Water Quality Association). The groundwater quality in some parts of the investigated area in this study has been examined by Hashem and Al-Johany in 1994 (Hashem and Al-Johany, 1994). The reported average TDS concentration was $1128 \pm 315 \mathrm{mg} \mathrm{L}^{-1}$ (median 992, range 800-1728). The average and median concentration values reported in our study are almost double the values reported in Hashem and AlJohany study. Similarly our results for TDS, sulfate, and chloride are slightly higher than those reported for the groundwater of Wadi Yalamlam basin, which is $\sim 500 \mathrm{~km}$ south of Almadinah Almunawarah (mean values for TDS, sulfate, and chloride were $1930 \pm 312 \mathrm{mg} \mathrm{L}^{-1}, 551 \pm 135 \mathrm{mg} \mathrm{L}^{-1}$, $758 \pm 62 \mathrm{mg} \mathrm{L}^{-1}$, respectively) (Subyani, 2005). Lower nitrate concentrations have been also reported during 1984-1988 for groundwater samples from the western side of KSA with $91 \%$ of the samples $(n=1659)$ has nitrate concentrations $<45 \mathrm{mg} \mathrm{L}^{-1}, 7 \%(n=131)<46-90 \mathrm{mg} \mathrm{L}^{-1}$, and $2 \%(n=$ 29) $<91-140 \mathrm{mg} \mathrm{L}^{-1}$. Similarly, $70 \%$ of the samples were found to contain TDS values $<1500 \mathrm{mg} \mathrm{L}^{-1}$ $(n=1266)$ (Alaa El-Din et al., 1994). On the other hand, slightly higher TDS and nitrate concentrations were reported for some groundwater samples collected from the western area of KSA in 1993 (TDS mean $455 \pm 312 \mathrm{mg} \mathrm{L}^{-1}$, range 210-1200 $\mathrm{mg} \mathrm{L}^{-1}, \mathrm{n}=23$ and nitrate mean $15.2 \pm$ $7.3 \mathrm{mg} \mathrm{L}^{-1}$, range $0.0-35 \mathrm{mg} \mathrm{L}^{-1}, \mathrm{n}=23$ ) (Alaa El-Din et al., 1993). Since these parameters are highly affected by dilution factors due to the difference in feeding rates during rainy and dry seasons, this variation is expected because the precipitation was low during the last 5 years. Also, the probable causes for the increase in the levels of dissolved solids in the investigated wells when compared to those reported in the previous studies for the same area would be leaching of soluble salts from the agricultural soil as well as the extensive depletion of groundwater reservoir, mainly for irrigation, along with low recharge rates (Al-Ahmadi and El-Fiky, 2009; Subyani, 2005).

Generally speaking, the groundwater of the investigated wells does not satisfy many of the general SASO drinking water guidelines and therefore needs proper pre-treatment before utilising as drinking water, but such a groundwater can safely be used for irrigation.

\section{Metals}

To ensure the quality of the results, various measures have been undertaken including the limit of detection (LOD), calibration verification checks (CVC), and analysis of certified reference materials. The results of these trials are listed in Table 2.

The LOD values for all analysed metals were in the range of $0.011-0.544 \mathrm{Mg} \mathrm{L}^{-1}$. The recoveries for the CVC when using a standard solution containing $25.0 \mu \mathrm{g} \mathrm{L}^{-1}$ of each metal prepared from a stock solution different from that used to construct the calibration curves were $94-104 \%$. On the other hand, the obtained metals concentrations for the CRMs were close enough to the certified values with recoveries ranging from 90 to $115 \%$ for all certified elements except $\mathrm{Pb}$, where its recovery was $78 \%$.

A summary of metals concentrations in the groundwater samples is presented in Table 3, whereas the detailed values are listed in Table 4. The average, standard deviation, median, and minimum values reported in Table 3 represent only the samples with concentrations $\geq$ LOD. Most of the samples are in compliance with the SASO and MAW guideline values for metals in drinking and irrigation water, respectively. None of the samples was found to contain $\mathrm{Cr}, \mathrm{Ni}, \mathrm{Cu}, \mathrm{Zn}, \mathrm{Cd}, \mathrm{Ba}$, and $\mathrm{Pb}$ above the guideline values. On the other hand, 3 samples (5\%) contained As slightly higher than the guideline value. These samples were GW21, GW22, and GW26 with As concentrations of 13.3 $\mu \mathrm{g} \mathrm{L}-1,12.0 \mu \mathrm{g} \mathrm{L}^{-1}$, and $29.0 \mu \mathrm{g} \mathrm{L}^{-1}$, respectively. Similarly, the amounts of Fe in 3 samples (GW37, 
GW48, and GW52, concentrations: $320 \mu \mathrm{g} \mathrm{L}^{-1}, 357 \mu \mathrm{g} \mathrm{L}^{-1}$, and $589 \mu \mathrm{g} \mathrm{L}^{-1}$, respectively) exceeded the guideline value. Only one sample (GW49) contained $\mathrm{Mn}\left(183 \mu \mathrm{g} \mathrm{L}^{-1}\right)$ over the guideline value. Finally, 6 samples (GW11, GW12, GW35, GW36, GW38, and GW41) were found to have Mg level higher than the guideline value with a range of $165-210 \mathrm{mg} \mathrm{L}^{-1}$.

Similarly, all the groundwater samples examined in this study are in compliance with MAW guidelines for irrigation water except 5 samples (GW29, GW32, GW37, GW38, and GW40), which were found to contain $\mathrm{Cr}$ (range $10.5-21.4 \mu \mathrm{g} \mathrm{L}^{-1}$ ) in excess of the guideline value (i.e. $10 \mu \mathrm{g} \mathrm{L}^{-1}$ ).

As there are no current industrials activities in the investigated area, the variations in the amounts of metals could be ascribed to the geological nature of the area. The level of water in wells and the feeding rates might explain the elevated contents of alkaline and alkaline earth metals (e.g., $\mathrm{Mg}$ and $\mathrm{Ca}$ ) and TDS in some samples. There is also possibility that $\mathrm{Cr}$ and As could have came from leather industry in the past.

The results of some metals reported in this work are lower than those reported for groundwater samples collected from the same locations about 17 years ago (Hashem and Al-Johany, 1994). The average reported concentrations in this latter study were $38 \mu \mathrm{g} \mathrm{L}^{-1}$ for $\mathrm{Co}(\max 110), 20 \mu \mathrm{g} \mathrm{L}^{-1}$ for Cu ( $\max 40 \mu \mathrm{g} \mathrm{L}^{-1}$ ), $106 \mu \mathrm{g} \mathrm{L}^{-1}$ for Fe (max $\left.320 \mu \mathrm{g} \mathrm{L}^{-1}\right), 29.4 \mu \mathrm{g} \mathrm{L}^{-1}$ for Mn $\left(\max 70 \mu \mathrm{g} \mathrm{L}^{-1}\right)$, and $373 \mu \mathrm{g} \mathrm{L}^{-1}$ for $\mathrm{Zn}\left(\max 530 \mu \mathrm{g} \mathrm{L}^{-1}\right)$. On the other hand, $\mathrm{Pb}$ was below the limit of detection (not specified) and the average $\mathrm{Mg}$ concentration was $38.0 \mathrm{mg} \mathrm{L}^{-1}$ ( $\left.\max 64.0 \mathrm{mg} \mathrm{L}^{-1}\right)$; both metals have lower average concentrations than those reported in our work. Additionally, the reported concentrations of metals in this work are also slightly lower than those reported for other areas in KSA (Al-Harbi et al., 2006; Assubaie, 2011 in press).

As evident from the findings of this study, most of the samples contain normal levels of metals with only $2-10 \%$ of the samples contained unacceptable, but not too high, concentrations of one or more of the following metals: As, Fe, Mn, and Mg. However, the status of these wells with respect to metals content as well as other quality parameters has to be periodically monitored in order to ensure their quality and identifying any sources of contamination if any. Based on these findings and due to the absence of heavy industries that usually contribute to the groundwater metal pollution in the City of Almadinah Almunawarah, it can be claimed that the groundwater in the investigated areas is relatively unpolluted concerning metal contamination. This should be clear when comparing the results of the groundwater samples examined in this work with those affected by industrial activities such as mining and petrochemical industries, which usually contain much higher concentrations of metals and other contaminants. For instance, copper mining and storage of obtained tailings in Sohar, Sultanate of Oman have been shown to result in elevated concentration of TDS (range 1000$\left.55000 \mathrm{mg} \mathrm{L}^{-1}\right), \mathrm{Pb}\left(300 \mu \mathrm{g} \mathrm{L}^{-1}\right), \mathrm{Cr}\left(<20 \mu \mathrm{g} \mathrm{L}^{-1}\right), \mathrm{Zn}\left(94000 \mu \mathrm{g} \mathrm{L}^{-1}\right)$, and $\mathrm{Ni}\left(40-1600 \mu \mathrm{g} \mathrm{L}^{-1}\right)$ (Sharma and Al-Busaidi, 2001). In another study, the groundwater in shallow aquifers underneath industrial activities in the Eastern Province of KSA has been also shown to be highly contaminated due to these activities. The reported mean concentrations of selected elements in the groundwater were $14.07 \pm 7.64 \mu \mathrm{g} \mathrm{L}^{-1}$ (range 5.99-37.4, $\mathrm{n}=20$ ) for $\mathrm{Cr}, 88.2 \pm 212 \mu \mathrm{g} \mathrm{L}^{-1}$ (range 0.08-1570 $\mu \mathrm{g} \mathrm{L}^{-1}, \mathrm{n}=$ 104) for $\mathrm{Pb}, 59.3 \pm 87.0 \mu \mathrm{g} \mathrm{L}^{-1}$ (range $0.18-552 \mu \mathrm{g} \mathrm{L}-1, \mathrm{n}=104$ ) for Mo, $5.05 \pm 3.59 \mu \mathrm{g} \mathrm{L}^{-1}$ (range $0.25-20.0 \mu \mathrm{g} \mathrm{L}^{-1}, \mathrm{n}=102$ ) for $\mathrm{Ni}, 23.4 \pm 19.6 \mathrm{mg} \mathrm{L}^{-1}$ (range $0.16-89.6 \mathrm{mg} \mathrm{L}^{-1}, \mathrm{n}=104$ ) for $\mathrm{Sr}$, and $70.6 \pm 73.4 \mu \mathrm{g} \mathrm{L}^{-1}$ (range 4.25-324 $\mathrm{g} \mathrm{L}^{-1}, \mathrm{n}=102$ ) for $\mathrm{Zn}$ (Sadiq and Alam, 1997). Such has been coused by leachate from industrial dust area, leakages from oil, and fertilizer industries.

\section{CONCLUSION}

Due to the policy of the government to keep the city of Almadinah Almunawarah free of heavy industries, the quality of groundwater in the investigated area is relatively good. However, some sort of water treatment is needed before using such wells for drinking purposes. Although most of the investigated wells satisfied the local drinking water guidelines for metals (i.e. only $2-10 \%$ of the samples exceeded the guideline value in one or more the following metals: As, $\mathrm{Fe}, \mathrm{Mn}, \mathrm{Mg}$ ), more than $75 \%$ of the samples can be considered as brackish. On the other hand, the water of most of the investigated wells can be used safely for irrigation purposes. It is recommended that the quality of the groundwater in the city and the surrounding areas are regularly monitored so as any irregularities can be identified early and dealt with in a cost effective manner. 
Table 1. Results of water general quality parameters along with local guideline values (the unit of all parameters, except color, turbidity, taste, odor, and $\mathrm{pH}$ is $\mathrm{mg} \mathrm{L}^{-1}$ )

\begin{tabular}{|c|c|c|c|c|c|c|c|c|c|c|c|c|c|c|}
\hline & $\begin{array}{l}\text { Color } \\
\text { (Unit a) }\end{array}$ & $\begin{array}{l}\text { Turbidity } \\
\text { (NTU) }\end{array}$ & Taste & Odor & $\mathrm{pH}$ & TDS & $\begin{array}{l}\text { Total } \\
\text { Hardness }\end{array}$ & $\begin{array}{l}\text { Nitrite } \\
\text { as N }\end{array}$ & $\begin{array}{l}\text { nitrate } \\
\text { as } \mathrm{N}\end{array}$ & Fluoride & Sodium & $\begin{array}{l}\text { Residual } \\
\text { Chlorine }\end{array}$ & Chloride & Sulfate \\
\hline Average & 2 & 0.7 & & & 7.41 & 2328 & 1051 & 0.046 & 80.2 & 0.89 & 471 & 0.016 & 752 & 733 \\
\hline $\begin{array}{l}\text { Standard } \\
\text { Deviation }\end{array}$ & 1 & 0.2 & not acceptable & accepta & 0.27 & 1419 & 697 & 0.127 & 69.3 & 0.43 & 348 & 0.008 & 545 & 432 \\
\hline Median & 2 & 0.7 & $\begin{array}{l}\text { for } 87 \% \text { of } \\
\text { samples }\end{array}$ & $\begin{array}{l}\text { ble for } \\
\text { all }\end{array}$ & 7.43 & 1975 & 927 & 0.007 & 64.0 & 0.83 & 385 & 0.010 & 625 & 700 \\
\hline Minimum & 0 & 0.2 & & samples & 6.92 & 119 & 56 & 0.000 & 3.52 & 0.01 & 24 & 0.010 & 44 & 19 \\
\hline Maximum & 4 & 1.2 & & & 8.00 & 6210 & 3500 & 0.710 & 429.0 & 2.16 & 1600 & 0.040 & 2462 & 2260 \\
\hline $\begin{array}{l}\text { SASO unbottled } \\
\text { drinking water } \\
\text { guidelines }\end{array}$ & 15 & 5 & acceptable & $\begin{array}{l}\text { accepta } \\
\text { ble }\end{array}$ & $\begin{array}{l}6.5- \\
8.5\end{array}$ & 1000 & 500 & 3 & 50 & 1.5 & 200 & 0.500 & 250 & 250 \\
\hline $\begin{array}{l}\text { MAW irrigation } \\
\text { water guidelines }\end{array}$ & $\begin{array}{l}\text { colorle } \\
\text { ss }\end{array}$ & --- & --- & --- & $\begin{array}{l}6.0- \\
8.4\end{array}$ & --- & --- & --- & 10.0 & 2.0 & --- & --- & --- & --- \\
\hline
\end{tabular}

a true color unit

Table 2. Quality control results for metals: concentrations in $\mu \mathrm{g} \mathrm{L}^{-1}$,

numbers in parentheses are the standard deviations of 3 replicates

\begin{tabular}{|c|c|c|c|c|c|c|c|c|c|c|c|c|c|c|c|}
\hline & ${ }^{24} \mathrm{Mg}$ & ${ }^{51} \mathrm{~V}$ & ${ }^{52} \mathrm{Cr}$ & ${ }^{55} \mathrm{Mn}$ & ${ }^{56} \mathrm{Fe}$ & ${ }^{59} \mathrm{Co}$ & ${ }^{60} \mathrm{Ni}$ & ${ }^{65} \mathrm{Cu}$ & ${ }^{66} \mathrm{Zn}$ & ${ }^{75} \mathrm{As}$ & ${ }^{88} \mathrm{Sr}$ & ${ }^{111} \mathrm{Cd}$ & ${ }^{137} \mathrm{Ba}$ & ${ }^{205} \mathrm{TI}$ & ${ }^{208} \mathrm{~Pb}$ \\
\hline LOD $^{a}$ & 0.161 & 0.043 & 0.146 & 0.083 & 0.544 & 0.015 & 0.023 & 0.097 & 0.158 & 0.011 & 0.059 & 0.038 & 0.051 & 0.027 & 0.069 \\
\hline CVC 25 & $\begin{array}{l}24.0 \\
(0.9)\end{array}$ & $\begin{array}{l}24.2 \\
(0.9)\end{array}$ & $\begin{array}{l}24.4 \\
(0.3)\end{array}$ & $\begin{array}{l}24.4 \\
(0.9)\end{array}$ & $\begin{array}{l}24.1 \\
(0.8)\end{array}$ & $\begin{array}{l}25.1 \\
(1.2)\end{array}$ & $\begin{array}{l}24.4 \\
(0.1)\end{array}$ & $\begin{array}{l}24.2 \\
(0.9)\end{array}$ & $\begin{array}{l}24.5 \\
(0.3)\end{array}$ & $\begin{array}{l}24.9 \\
(0.8)\end{array}$ & $\begin{array}{l}24.4 \\
(0.7)\end{array}$ & $\begin{array}{l}24.9 \\
(0.7)\end{array}$ & $\begin{array}{l}24.1 \\
(0.4)\end{array}$ & $\begin{array}{l}25.2 \\
(1.1)\end{array}$ & $\begin{array}{l}26.0 \\
(0.8)\end{array}$ \\
\hline $\begin{array}{l}\text { CRM TM- } \\
26.3 \text {, } \\
\text { obtained }\end{array}$ & $\begin{array}{l}4270 \\
(97.4)\end{array}$ & $\begin{array}{l}13.1 \\
(1.3)\end{array}$ & $\begin{array}{l}11.2 \\
(0.3)\end{array}$ & $\begin{array}{l}17.1 \\
(0.8)\end{array}$ & $\begin{array}{l}20.0 \\
(1.9)\end{array}$ & $\begin{array}{l}8.56 \\
(0.2)\end{array}$ & $\begin{array}{l}10.3 \\
(0.3)\end{array}$ & $\begin{array}{l}12.6 \\
(0.8)\end{array}$ & $\begin{array}{l}58.0 \\
(0.8)\end{array}$ & $\begin{array}{l}8.10 \\
(0.2)\end{array}$ & $\begin{array}{l}99.5 \\
(2.1)\end{array}$ & $\begin{array}{l}8.16 \\
(0.8)\end{array}$ & $\begin{array}{l}22.5 \\
(2.1)\end{array}$ & $\begin{array}{l}5.16 \\
(0.3)\end{array}$ & $\begin{array}{l}8.23 \\
(0.5)\end{array}$ \\
\hline $\begin{array}{l}\text { CRM TM- } \\
26.3 \text {, } \\
\text { certified }\end{array}$ & $\begin{array}{l}4173^{b} \\
(156)\end{array}$ & 12.1 & $\begin{array}{l}12.3 \\
(4.2)\end{array}$ & $\begin{array}{l}17.0 \\
(1.8)\end{array}$ & 21 & $\begin{array}{l}8.1 \\
(0.9)\end{array}$ & $\begin{array}{l}10.2 \\
(1.1)\end{array}$ & $\begin{array}{l}13.4 \\
(1.1)\end{array}$ & $39^{c}$ & $\begin{array}{l}7.9 \\
(0.8)\end{array}$ & 96 & $\begin{array}{l}7.1 \\
(0.3)\end{array}$ & $\begin{array}{l}25 \\
(1.2)\end{array}$ & 5.2 & $\begin{array}{l}9.3 \\
(0.7)\end{array}$ \\
\hline
\end{tabular}

a LOD: limit of detection ( $3 \times$ standard deviation of 5-7 blank readings measured at different times during the run).

$\mathrm{b}$ This value is for $\mathrm{Mg}$ in the certified wastewater CWW-TM-D.

c No certified value was provided, instead, an information value was used. 
Table 3. Summary of metals concentrations ( $\mu \mathrm{g} \mathrm{L}^{-1}$, unit for $M g$ is $\mathrm{mg} \mathrm{L}^{-1}$ ) in the samples

\begin{tabular}{|c|c|c|c|c|c|c|c|c|c|c|c|c|c|c|c|}
\hline & ${ }^{24} \mathrm{Mg}$ & ${ }^{51} \mathrm{~V}$ & ${ }^{52} \mathrm{Cr}$ & ${ }^{55} \mathrm{Mn}$ & ${ }^{56} \mathrm{Fe}$ & ${ }^{59} \mathrm{Co}$ & ${ }^{60} \mathrm{Ni}$ & ${ }^{65} \mathrm{Cu}$ & ${ }^{66} \mathrm{Zn}$ & ${ }^{75} \mathrm{As}$ & ${ }^{88} \mathrm{Sr}$ & ${ }^{111} \mathrm{Cd}$ & ${ }^{137} \mathrm{Ba}$ & ${ }^{205} \mathrm{TI}$ & ${ }^{208} \mathrm{~Pb}$ \\
\hline $\begin{array}{l}\% \text { Samples with } \\
\text { results >LOD }\end{array}$ & 100 & 100 & 67 & 47 & 97 & 82 & 40 & 8 & 58 & 98 & 100 & 8 & 100 & 33 & 97 \\
\hline $\begin{array}{l}\% \text { Samples with } \\
\text { results >SASO } \\
\text { guideline value }\end{array}$ & 10.0 & --- & 0.0 & 1.7 & 5.0 & --- & 0.0 & 0.0 & 0.0 & 5.0 & --- & 0.0 & 0.0 & --- & 0.0 \\
\hline Average a & 74.0 & 21.4 & 5.25 & 10.6 & 44.4 & 0.502 & 0.856 & 2.72 & 23.6 & 2.26 & 3816 & 0.785 & 28.8 & 0.989 & 0.957 \\
\hline $\begin{array}{l}\text { Standard } \\
\text { deviation a }\end{array}$ & 53.4 & 14.8 & 5.00 & 35.7 & 103 & 0.224 & 0.918 & 3.87 & 33.6 & 4.37 & 2639 & 0.344 & 27.1 & 0.116 & 0.785 \\
\hline Median a & 68.6 & 19.6 & 3.77 & 1.32 & 10.2 & 0.493 & 0.675 & 0.759 & 8.83 & 1.18 & 3630 & 0.807 & 20.9 & 0.963 & 0.590 \\
\hline Minimum a & 25.6 & 2.13 & 0.360 & 0.080 & 0.471 & 0.054 & 0.064 & 0.409 & 0.640 & 0.090 & 51.4 & 0.424 & 0.522 & 0.961 & 0.195 \\
\hline $\begin{array}{l}\text { Maximum } \\
\text { SASO unbottled }\end{array}$ & 210 & 89.9 & 21.4 & 183 & 589 & 1.33 & 4.78 & 9.53 & 134 & 29.0 & 12200 & 1.30 & 116 & 1.48 & 3.86 \\
\hline $\begin{array}{l}\text { drinking water } \\
\text { guidelines }\end{array}$ & 150 & --- & 50 & 100 & 300 & --- & 20 & 1000 & 2000 & 10 & --- & 3 & 700 & --- & 10 \\
\hline $\begin{array}{l}\text { MAW irrigation } \\
\text { water guidelines }\end{array}$ & --- & 10 & 10 & 200 & 5000 & 50 & 20 & 400 & 4000 & 100 & --- & 10 & --- & --- & 100 \\
\hline
\end{tabular}

SASO: Saudi Arabian Standards Organisation standard no. 701.

MAW: Ministry of Agriculture and Water, Saudi Arabia.

a only samples with concentrations $\geq M D L$ were included in these statistics.

Table 4. Concentrations of metals ( $\mu \mathrm{g} \mathrm{L}^{-1}$ for all except $\mathrm{Mg}$ and $\mathrm{Sr}$ which is $\mathrm{mg} \mathrm{L}^{-1}$ ) in the samples rounded to 3 significant digits

\begin{tabular}{|c|c|c|c|c|c|c|c|c|c|c|c|c|c|c|c|}
\hline $\begin{array}{c}\text { Sample } \\
\text { ID }\end{array}$ & ${ }^{24} \mathrm{Mg}$ & ${ }^{51} \mathrm{~V}$ & ${ }^{52} \mathrm{Cr}$ & ${ }^{55} \mathrm{Mn}$ & ${ }^{56} \mathrm{Fe}$ & ${ }^{59} \mathrm{Co}$ & ${ }^{60} \mathrm{Ni}$ & ${ }^{65} \mathrm{Cu}$ & ${ }^{66} \mathrm{Zn}$ & ${ }^{75}$ As & ${ }^{88} \mathrm{Sr}$ & ${ }^{111} \mathrm{Cd}$ & ${ }^{137} \mathrm{Ba}$ & ${ }^{205} \mathrm{TI}$ & ${ }^{208} \mathrm{~Pb}$ \\
\hline GW 1 & 78.3 & 25.6 & 4.46 & 0.380 & 18.9 & 0.488 & $<$ LOD & $<$ LOD & 16.1 & 0.277 & 1.83 & $<L O D$ & 14.8 & $<L O D$ & 0.195 \\
\hline GW 2 & 79.6 & 19.7 & 1.43 & 0.549 & 56.0 & 0.591 & 0.069 & 0.698 & 12.1 & 1.15 & 4.09 & $<L O D$ & 32.8 & $<L O D$ & 0.581 \\
\hline GW 3 & 118 & 24.8 & 4.00 & $<L O D$ & 2.10 & 0.517 & 0.484 & $<$ LOD & 0.882 & 0.339 & 2.55 & $<L O D$ & 23.8 & $<L O D$ & $<$ LOD \\
\hline GW 4 & 29.8 & 89.9 & 2.73 & $<$ LOD & 5.16 & 0.631 & $<$ LOD & $<L O D$ & 27.2 & 7.50 & 0.863 & 0.874 & 7.76 & $<L O D$ & 3.86 \\
\hline GW 5 & 95.4 & 25.3 & 5.40 & $<L O D$ & 5.62 & 0.490 & $<L O D$ & $<L O D$ & 4.12 & 0.429 & 2.25 & $<L O D$ & 22.7 & $<L O D$ & 1.29 \\
\hline GW 6 & 31.4 & 12.8 & 0.876 & 0.650 & 15.1 & 0.518 & 0.209 & $<L O D$ & 1.40 & 2.65 & 1.94 & $<L O D$ & 17.2 & $<L O D$ & 0.306 \\
\hline GW 7 & 35.3 & 14.4 & 0.915 & $<$ LOD & 14.9 & 0.489 & 0.780 & $<L O D$ & 4.27 & 3.01 & 2.61 & $<$ LOD & 17.3 & $<$ LOD & 1.56 \\
\hline GW 8 & 85.5 & 27.0 & 1.79 & 0.380 & 0.471 & 0.628 & $<$ LOD & $<$ LOD & $<$ LOD & 1.19 & 3.58 & 0.807 & 23.1 & $<L O D$ & 3.46 \\
\hline GW 9 & 77.3 & 42.4 & 1.19 & 0.416 & 26.7 & 1.33 & 0.595 & $<L O D$ & $<L O D$ & 3.59 & 3.02 & $<L O D$ & 19.5 & $<L O D$ & 0.922 \\
\hline GW 10 & 103 & 19.2 & 2.90 & $<$ LOD & 17.6 & 0.500 & $<$ LOD & $<L O D$ & 11.2 & 0.490 & 4.38 & $<$ LOD & 23.2 & $<L O D$ & 0.845 \\
\hline
\end{tabular}


Table 4 (continued). Concentrations of metals ( $\mu \mathrm{g} \mathrm{L}^{-1}$ for all except $\mathrm{Mg}$ and $\mathrm{Sr}$ which is $\left.\mathrm{mg} \mathrm{L}^{-1}\right)$ in the samples rounded to 3 significant digits

\begin{tabular}{|c|c|c|c|c|c|c|c|c|c|c|c|c|c|c|c|}
\hline $\begin{array}{c}\text { Sample } \\
\text { ID }\end{array}$ & ${ }^{24} \mathrm{Mg}$ & ${ }^{51} \mathrm{~V}$ & ${ }^{52} \mathrm{Cr}$ & ${ }^{55} \mathrm{Mn}$ & ${ }^{56} \mathrm{Fe}$ & ${ }^{59} \mathrm{Co}$ & ${ }^{60} \mathrm{Ni}$ & ${ }^{65} \mathrm{Cu}$ & ${ }^{66} \mathrm{Zn}$ & ${ }^{75}$ As & ${ }^{88} \mathrm{Sr}$ & ${ }^{111} \mathrm{Cd}$ & ${ }^{137} \mathrm{Ba}$ & ${ }^{205} \mathrm{TI}$ & ${ }^{208} \mathrm{~Pb}$ \\
\hline GW 11 & 206 & 22.7 & 5.53 & $<$ LOD & 6.75 & 0.493 & $<L O D$ & $<$ LOD & $<$ LOD & 0.364 & 4.87 & $<$ LOD & 32.6 & $<$ LOD & 0.217 \\
\hline GW 12 & 165 & 18.4 & 3.12 & 0.472 & 143 & 0.476 & $<L O D$ & 0.409 & 20.2 & 0.451 & 5.26 & $<\mathrm{LOD}$ & 30.8 & $<\mathrm{LOD}$ & 0.389 \\
\hline GW 13 & 109 & 11.3 & 0.590 & $<L O D$ & $<\mathrm{LOD}$ & 0.485 & $<L O D$ & $<L O D$ & $<\mathrm{LOD}$ & 0.250 & 7.46 & $<\mathrm{LOD}$ & 12.3 & $<L O D$ & $<L O D$ \\
\hline GW 14 & 33.3 & 44.1 & 3.54 & $<L O D$ & $<L O D$ & 0.697 & $<L O D$ & $<$ LOD & $<L O D$ & 2.87 & 1.24 & $<L O D$ & 13.4 & $<L O D$ & 0.404 \\
\hline GW 15 & 146 & 24.1 & 4.36 & $<$ LOD & 0.703 & 0.505 & $<L O D$ & $<$ LOD & $<L O D$ & 0.387 & 3.68 & 1.30 & 33.7 & $<$ LOD & 0.276 \\
\hline GW 16 & 39.9 & 68.6 & 7.38 & $<L O D$ & 9.98 & 0.523 & $<L O D$ & $<L O D$ & 122 & 1.47 & 0.822 & $<L O D$ & 9.53 & $<L O D$ & 0.393 \\
\hline GW 17 & 83.9 & 32.5 & 7.40 & $<L O D$ & 13.0 & 0.452 & $<$ LOD & $<$ LOD & 3.32 & 0.395 & 1.35 & $<L O D$ & 14.9 & $<L O D$ & 0.398 \\
\hline GW 18 & 149 & 19.9 & 2.60 & $<L O D$ & 2.09 & 0.485 & $<L O D$ & $<$ LOD & 0.959 & 0.393 & 5.22 & $<L O D$ & 21.4 & $<L O D$ & 0.220 \\
\hline GW 19 & 75.2 & 20.3 & 1.59 & 0.746 & 11.2 & 0.637 & $<L O D$ & $<$ LOD & 5.32 & 1.18 & 4.11 & $<$ LOD & 32.7 & $<$ LOD & 0.500 \\
\hline GW 20 & 73.7 & 19.8 & 1.77 & $<L O D$ & 10.5 & 0.650 & $<L O D$ & $<L O D$ & $<L O D$ & 1.22 & 3.96 & $<\mathrm{LOD}$ & 34.1 & $<\mathrm{LOD}$ & 0.810 \\
\hline GW 21 & 20.9 & 4.20 & 0.360 & 4.78 & 12.5 & 0.615 & 0.339 & $<$ LOD & $<L O D$ & 13.3 & 8.79 & 0.424 & 12.0 & $<L O D$ & 0.389 \\
\hline GW 22 & 21.9 & 11.8 & 0.530 & 2.45 & 14.7 & 0.613 & $<L O D$ & $<$ LOD & $<L O D$ & 12.0 & 5.40 & $<$ LOD & 16.8 & $<L O D$ & 0.303 \\
\hline GW 23 & 110 & 34.8 & 9.49 & $<L O D$ & 1.89 & 0.739 & $<L O D$ & $<L O D$ & $<\mathrm{LOD}$ & 0.152 & 1.33 & $<\mathrm{LOD}$ & 3.25 & $<\mathrm{LOD}$ & 0.308 \\
\hline GW 24 & 64.4 & 12.9 & 1.70 & 0.227 & 17.5 & 0.483 & $<L O D$ & $<$ LOD & 4.92 & 3.43 & 6.80 & $<\mathrm{LOD}$ & 19.8 & $<L O D$ & 0.267 \\
\hline GW 25 & 2.56 & 21.7 & 1.22 & $<$ LOD & 5.45 & 0.427 & $<L O D$ & $<$ LOD & $<L O D$ & 7.41 & 0.385 & $<\mathrm{LOD}$ & 6.26 & $<L O D$ & 0.467 \\
\hline GW 26 & 3.54 & 11.3 & 0.546 & $<$ LOD & 4.89 & 0.422 & $<L O D$ & $<$ LOD & 31.1 & 29.0 & 0.516 & $<L O D$ & 21.8 & $<L O D$ & 0.599 \\
\hline GW 27 & 73.7 & 32.4 & 3.02 & $<L O D$ & 5.22 & 0.604 & $<L O D$ & $<L O D$ & $<\mathrm{LOD}$ & 0.405 & 1.73 & $<L O D$ & 15.6 & $<\mathrm{LOD}$ & 0.256 \\
\hline GW 28 & 74.7 & 21.2 & 5.11 & $<L O D$ & 4.82 & 0.552 & $<L O D$ & $<L O D$ & $<L O D$ & 0.152 & 1.61 & $<\mathrm{LOD}$ & 21.0 & $<\mathrm{LOD}$ & 0.229 \\
\hline GW 29 & 113 & 20.7 & 11.8 & $<$ LOD & 4.52 & 0.447 & $<L O D$ & $<$ LOD & $<L O D$ & 0.255 & 3.56 & $<L O D$ & 40.0 & $<L O D$ & 0.276 \\
\hline GW 30 & 54.9 & 27.0 & 4.42 & 1.33 & 2.98 & 0.658 & $<L O D$ & $<$ LOD & $<L O D$ & 0.212 & 1.03 & $<L O D$ & 8.35 & $<L O D$ & 0.298 \\
\hline GW 31 & 100 & 19.5 & 5.63 & $<L O D$ & 3.25 & 0.489 & $<L O D$ & $<L O D$ & $<L O D$ & 0.205 & 2.93 & $<\mathrm{LOD}$ & 61.7 & $<\mathrm{LOD}$ & 0.258 \\
\hline GW 32 & 72.8 & 25.4 & 10.5 & $<L O D$ & 5.30 & 0.584 & $<$ LOD & $<$ LOD & 2.34 & 0.175 & 1.14 & $<L O D$ & 3.00 & $<L O D$ & 0.428 \\
\hline GW 33 & 96.5 & 16.5 & 5.98 & $<L O D$ & 6.44 & 0.482 & $<L O D$ & $<$ LOD & $<L O D$ & 0.090 & 2.12 & $<L O D$ & 24.4 & $<L O D$ & 0.250 \\
\hline GW 34 & 76.2 & 17.6 & 9.77 & 0.080 & 11.5 & 0.446 & $<L O D$ & $<$ LOD & 1.43 & 0.435 & 5.79 & $<$ LOD & 59.9 & $<$ LOD & 0.281 \\
\hline GW 35 & 210 & 14.4 & 8.99 & $<L O D$ & 9.06 & 0.468 & $<L O D$ & $<L O D$ & 4.81 & 0.125 & 4.51 & $<L O D$ & 11.2 & $<L O D$ & 0.240 \\
\hline GW 36 & 209 & 14.1 & 8.13 & $<L O D$ & 8.44 & 0.467 & $<L O D$ & $<$ LOD & 6.37 & 0.181 & 4.54 & $<L O D$ & 15.3 & $<L O D$ & 0.256 \\
\hline GW 37 & 8.94 & 36.9 & 16.5 & 3.76 & 320 & 0.491 & $<L O D$ & $<$ LOD & 82.9 & 2.34 & 0.278 & $<L O D$ & 5.21 & $<L O D$ & 1.15 \\
\hline GW 38 & 196 & 16.4 & 18.6 & $<L O D$ & 25.9 & 0.586 & $<$ LOD & $<L O D$ & 8.07 & 0.151 & 3.88 & $<$ LOD & 11.0 & $<$ LOD & 0.223 \\
\hline GW 39 & 3.12 & 2.10 & 2.65 & 1.31 & 39.8 & 0.555 & 4.78 & 9.53 & 28.0 & $<\mathrm{LOD}$ & 0.051 & $<\mathrm{LOD}$ & 0.522 & $<\mathrm{LOD}$ & 0.550 \\
\hline GW 40 & 119 & 41.9 & 21.4 & $<L O D$ & 38.1 & 0.558 & $<L O D$ & $<$ LOD & 2.50 & 0.282 & 2.04 & $<L O D$ & 2.83 & $<L O D$ & 0.340 \\
\hline GW 41 & 159 & 12.1 & $\angle L O D$ & $<L O D$ & 13.2 & $<L O D$ & 0.850 & $<L O D$ & $<$ LOD & 1.41 & 12.2 & $<$ LOD & 25.5 & 0.964 & 1.38 \\
\hline
\end{tabular}

<LOD means: concentration is below limit of detection 
Table 4 (continued). Concentrations of metals ( $\mu \mathrm{g} \mathrm{L}^{-1}$ for all except $\mathrm{Mg}$ and $\mathrm{Sr}$ which is $\mathrm{mg} \mathrm{L}^{-1}$ ) in the samples rounded to 3 significant digits

\begin{tabular}{|c|c|c|c|c|c|c|c|c|c|c|c|c|c|c|c|}
\hline $\begin{array}{c}\text { Sample } \\
\text { ID }\end{array}$ & 24 $\mathrm{Mg}$ & ${ }^{51} \mathrm{~V}$ & ${ }^{52} \mathrm{Cr}$ & 55 $\mathrm{Mn}$ & ${ }^{56} \mathrm{Fe}$ & ${ }^{59} \mathrm{Co}$ & ${ }^{60} \mathrm{Ni}$ & ${ }^{65} \mathrm{Cu}$ & ${ }^{66} \mathrm{Zn}$ & ${ }^{75}$ As & ${ }^{88} \mathrm{Sr}$ & ${ }^{111} \mathrm{Cd}$ & ${ }^{137} \mathrm{Ba}$ & ${ }^{205} \mathrm{TI}$ & ${ }^{208} \mathrm{~Pb}$ \\
\hline GW 42 & 30.8 & 6.10 & $<$ LOD & 6.37 & 8.27 & $<$ LOD & 0.753 & $<$ LOD & $<$ LOD & 1.64 & 5.70 & $<L O D$ & 55.7 & 0.964 & 1.51 \\
\hline GW 43 & 57.8 & 14.1 & $<L O D$ & 2.07 & 261 & 0.090 & 0.605 & $<L O D$ & 12.9 & 1.58 & 7.19 & $<\mathrm{LOD}$ & 112 & 0.962 & 1.78 \\
\hline GW 44 & 21.4 & 7.90 & $<L O D$ & 0.185 & 20.3 & 0.146 & 0.738 & $<L O D$ & 38.5 & 3.06 & 2.63 & $<L O D$ & 113 & 0.962 & 1.74 \\
\hline GW 45 & 41.9 & 8.20 & $<L O D$ & 0.278 & 16.0 & 0.055 & 0.777 & $<$ LOD & 8.83 & 1.39 & 5.94 & 0.521 & 116 & 0.963 & 1.54 \\
\hline GW 46 & 24.7 & 8.40 & $<L O D$ & 2.16 & 170 & 0.054 & 0.416 & $<L O D$ & 90.2 & 1.77 & 4.39 & $<\mathrm{LOD}$ & 50.7 & 0.961 & 1.64 \\
\hline GW 47 & 52.1 & 6.40 & $<L O D$ & 2.90 & 115 & $<L O D$ & 0.591 & $<L O D$ & $<L O D$ & 1.24 & 8.37 & $<\mathrm{LOD}$ & 25.5 & 0.962 & 1.40 \\
\hline GW 48 & 37.3 & 8.2 & $<L O D$ & 2.27 & 357 & 0.091 & 1.18 & 0.759 & 134 & 1.61 & 5.16 & $<L O D$ & 36.5 & 0.966 & 1.60 \\
\hline GW 49 & 36.4 & 5.9 & $<L O D$ & 183 & 14.1 & $<L O D$ & 0.730 & $<$ LOD & $<$ LOD & 0.911 & 6.36 & $<L O D$ & 22.1 & 0.967 & 1.50 \\
\hline GW 50 & 27.9 & 12.0 & $<L O D$ & 1.76 & 47.2 & $<L O D$ & 1.75 & 2.18 & 24.5 & 1.64 & 5.58 & $<\mathrm{LOD}$ & 87.4 & 0.964 & 1.61 \\
\hline GW 51 & 27.9 & 20.3 & $<L O D$ & $<L O D$ & 5.73 & $<L O D$ & 0.064 & $<L O D$ & 2.86 & 2.14 & 1.91 & $<\mathrm{LOD}$ & 48.4 & 0.965 & 1.58 \\
\hline GW 52 & 120 & 4.60 & $<L O D$ & 61.1 & 589 & 0.129 & 0.519 & $<$ LOD & $<L O D$ & 0.342 & 9.90 & $<L O D$ & 4.72 & 0.963 & 1.45 \\
\hline GW 53 & 91.2 & 16.9 & $<$ LOD & 0.133 & 8.26 & $<$ LOD & 0.523 & $<$ LOD & $<L O D$ & 4.43 & 8.21 & $<L O D$ & 50.4 & 0.964 & 1.48 \\
\hline GW 54 & 50.1 & 7.10 & $<L O D$ & 3.18 & 12.0 & 0.699 & 1.36 & $<$ LOD & 24.4 & 1.73 & 4.78 & $<L O D$ & 91.1 & 1.48 & 1.91 \\
\hline GW 55 & 48.1 & 17.0 & $<L O D$ & $<L O D$ & 3.79 & $<L O D$ & 0.782 & $<L O D$ & 38.2 & 3.08 & 5.17 & $<\mathrm{LOD}$ & 19.7 & 0.965 & 1.51 \\
\hline GW 56 & 49.3 & 21.4 & $<L O D$ & 11.9 & 9.20 & 0.971 & 0.619 & $<L O D$ & 43.6 & 0.330 & 6.70 & $<$ LOD & 11.7 & 0.962 & 1.59 \\
\hline GW 57 & 12.9 & 31.7 & $<L O D$ & $<$ LOD & 8.43 & $<$ LOD & $<L O D$ & $<$ LOD & $<$ LOD & 1.67 & 0.801 & $<L O D$ & 17.6 & 0.961 & 1.65 \\
\hline GW 58 & 47.5 & 23.5 & $<L O D$ & $<L O D$ & 2.79 & $<L O D$ & $<L O D$ & $<L O D$ & 5.19 & 0.934 & 2.06 & $<\mathrm{LOD}$ & 20.8 & 0.961 & 1.54 \\
\hline GW 59 & 40.8 & 33.1 & $<L O D$ & $<L O D$ & 7.33 & $<L O D$ & $<L O D$ & $<L O D$ & 0.640 & 0.701 & 1.19 & $<L O D$ & 7.82 & 0.961 & 1.59 \\
\hline GW 60 & 18.7 & 33.2 & $<L O D$ & 0.663 & 6.03 & 0.081 & 1.02 & $<L O D$ & $<L O D$ & 2.03 & 1.23 & $<\mathrm{LOD}$ & 14.5 & 0.963 & 1.54 \\
\hline
\end{tabular}




\section{REFERENCES}

Al-Ahmadi, M. E. and A. A. El-Fiky (2009), Hydrogeochemical evaluation of shallow alluvial aquifer of Wadi Marwani, western Saudi Arabia, J King Saud U - Sci, 21(3), 179-190.

Al-Harbi, O. A., G. Hussain, M. M. Khan, M. A. Moallim and I. A. Al-Sagaby (2006), Evaluation of groundwater quality and its recharge by isotopes and solute chemistry in Wadi Malal, Al-Madinah AlMunawarah, Saudi Arabia, Pak J Biol Sci, 9(2), 260-269.

Al-Senafy, M. and J. Abraham (2004), Vulnerability of groundwater resources from agricultural activities in southern Kuwait, Agr Water Mang, 64(1), 1-15.

Alaa El-Din, M. N., I. M. Madany, A. Al-Tayaran, A. H. Al-Jubair and A. Gomaa (1993), Quality of water from some wells in saudi arabia, Water Air Soil Poll, 66(1), 135-143.

Alaa El-Din, M. N., I. M. Madany, A. Al-Tayaran, A. Hakeem Al-Jubair and A. Gomaa (1994), Trends in water quality of some wells in Saudi Arabia, 1984-1989, Sci Tot Environ, 143(2-3), 173-181.

Alhumoud, J. M., F. M. Al-Ruwaih and Z. M. Al-Dhafeeri (2010), Groundwater quality analysis of limestone aquifer of Al-Sulaibiya field, Kuwait, Desalination, 254(1-3), 58-67.

Almadinah Almunawarah Encyclopedia, accessed on 14/07/2012. from http://www.al3ez.net/mag/main page.htm.

Alsharhan, A. S., Z. A. Rizk, A. E. M. Nairn, D. W. Bakhit and S. A. Alhajari (2001). Chapter 1 - An introduction to water resources in the Arabian Peninsula. Hydrogeology of an Arid Region: The Arabian Gulf and Adjoining Areas. Amsterdam, Elsevier Science B.V.: 1-6.

Assubaie, F. N. (2011 in press), Assessment of the levels of some heavy metals in water in Alahsa Oasis farms, Saudi Arabia, with analysis by atomic absorption spectrophotometry, Arab J Chem.

Haddadin, M. J. (2002), Water issues in the Middle East challenges and opportunities, Water Policy, 4(3), 205-222.

Hashem, A. R. and A. M. Al-Johany (1994), Elemental concentration of selected soil and water samples from Al-Madinah area, Saudi Arabia, J King Saud U, Sci, 6(2), 127-136.

Husain, T., H. U. Khan and S. M. Khan (1991), Evaluation of water resources alternatives in saudi arabia in multi-objective framework, Desalination, 81(1-3), 77-79.

Murad, A. A. and R. V. Krishnamurthy (2004), Factors controlling groundwater quality in Eastern United Arab Emirates: a chemical and isotopic approach, J Hydrol, 286(1-4), 227-235.

Sadiq, M. and I. Alam (1997), Metal concentrations in a shallow groundwater aquifer underneath petrochemical complex, Water Res, 31(12), 3089-3097.

Saudi Arabia Ministry of Economy and Planning (2004). The Statistical Yearbook for 2004. Central Department of Statistics. 40.

Sharma, R. S. and T. S. Al-Busaidi (2001), Groundwater pollution due to a tailings dam, Eng Geol, 60(14), $235-244$.

Shraim, A., A. Alsuhaimi and J. T. Al-Thakafy (2011), Dental clinics: A point pollution source, not only of mercury but also of other amalgam constituents, Chemosphere, 84(8), 1133-1139.

Subyani, A. M. (2005), Hydrochemical identification and salinity problem of ground-water in Wadi Yalamlam basin, Western Saudi Arabia, J Arid Environ, 60(1), 53-66.

Water Quality Association, accessed on 14/07/2012. from www.pacificro.com/watercla.htm.

Weatherbase, accessed on from http://www.weatherbase.com/weather/weather.php3?s=3404\&refer=\&cityname=Medina-SaudiArabia. 